\title{
A Novel Drug Design Strategy: An Inspiration from Encaging Tumor by Metallofullerenol Gd@ $\mathrm{C}_{82}(\mathrm{OH})_{22}$
}

\author{
Jinxia Li ${ }^{1}$, Linlin Chen ${ }^{2}$, Liang Yan ${ }^{1}$, Zhanjun Gu ${ }^{1}$, Zhaofang Chen ${ }^{3}$, Aiping Zhang ${ }^{2}$ \\ and Feng Zhao ${ }^{1, * \mathbb{D}}$ \\ 1 CAS Key Laboratory for Biomedical Effects of Nanomaterials and Nanosafety, Institute of High Energy \\ Physics, Chinese Academy of Sciences (CAS), Beijing 100049, China \\ 2 College of Pharmacy, Shanxi Medical University, Taiyuan 030001, China \\ 3 Jiangsu Key Laboratory of Hazardous Chemicals Safety and Control, College of Safety Science and \\ Engineering, Nanjing Tech University, Nanjing 210009, China \\ * Correspondence: zhaof@ihep.ac.cn; Tel.: +86-010-88235074
}

Received: 9 June 2019; Accepted: 26 June 2019; Published: 27 June 2019

\begin{abstract}
Cancer remains a major threat to human health worldwide. Cytotoxicity has imposed restrictions on the conventional cytotoxic drug-based chemotherapy. The rapidly-developing nanomedicine has shown great promise in revolutionizing chemotherapy with improved efficiency and reduced toxicity. Gd@ $\mathrm{C}_{82}(\mathrm{OH})_{22}$, a novel endohedral metallofullerenol, was first reported by our research group to suppress tumor growth and metastasis efficiently without obvious toxicity. $\mathrm{Gd} @ \mathrm{C}_{82}(\mathrm{OH})_{22}$ imprisons tumors by facilitating the formation of surrounding fibrous layers which is different from chemotherapeutics that poison tumor cells. In this review, the authors first reported the antineoplastic activity of metallofullerenol Gd@ $\mathrm{C}_{82}(\mathrm{OH})_{22}$ followed by further discussions on its new anti-cancer molecular mechanism-tumor encaging. On this basis, the unparalleled advantages of nanomedicine in the future drug design are discussed. The unique interaction modes of $\mathrm{Gd} @ \mathrm{C}_{82}(\mathrm{OH})_{22}$ with specific targeted biomolecules may shed light on a new avenue for drug design. Depending on the surface characteristics of target biomolecules, nanomedicine, just like a transformable and dynamic key, can self-assemble into suitable shapes to match several locks for the thermodynamic stability, suggesting the target-tailoring ability of nanomedicine.
\end{abstract}

Keywords: metallofullerenol; $\mathrm{Gd}_{\mathrm{C}} \mathrm{C}_{82}(\mathrm{OH})_{22}$; encaging tumor; drug design; key and lock principle

\section{Introduction}

According to the latest cancer statistics issued by the American Cancer Society in 2019, the death rate from all cancers combined has declined by $27 \%$ since 1991 owing to increased awareness, decreased smoking and progression made in early detection and treatment [1]. However, cancer, as a leading cause of morbidity and mortality, still remains a major threat to human health worldwide [2]. In the USA, 1,762,450 new cancer cases have been reported in 2019 and 606,880 deaths are projected to occur in 2019 [1]. Globally, an alarming increase in the incidence of all-cancer cases has been estimated from 12.7 million new cases in 2008 to 22.2 million by 2030 [3]. The large threat of cancer to human health has posed a great challenge for medical practice in cancer diagnosis and treatment.

Currently, three principle strategies available to treat cancers are still confined to surgery, chemotherapy and radiotherapy [4]. Either mechanical removal of tumors by surgery or direct destruction of malignant cells by poisoning or irradiating inevitably induces unsatisfactory outcomes. Chemotherapy, dependent on the cytotoxic effects of chemotherapeutics, has witnessed high occurrences of severe side effects due to its unselective damage both to tumor and normal tissues [5]. In some cases, patients suffer so much that chemotherapy is forced to be terminated. More importantly, 
multidrug resistance is another challenge confronted by chemotherapy, which significantly limits the effectiveness of chemotherapy and impedes the progress of patient prognosis [6,7]. Approximately, $90 \%$ of deaths from ovarian cancer could be attributed to multidrug resistance [8]. Despite the emergence of molecular-targeted chemotherapy with enhanced selectivity in late decades, adverse reactions are still unavoidable which, at least partially, is attributed to the diversity and complexity of target biomolecules $[9,10]$. Therefore, a new anti-cancer strategy is in great need to reduce or even avoid the risks of severe toxicity resulting from the traditional chemotherapy.

Encouragingly, the recent rapidly-developing nanotechnology offers great opportunities to improve the antineoplastic efficiency and simultaneously smooth away the drawbacks of traditional chemotherapy [11]. Globally, intensive research on the development of clinic-aimed nanotechnology has attracted increasing attention as an emerging hotspot of the nanoscience field. Nationally, facing the global competitions, our government has urgently encouraged the acceleration of the development of nanotechnology with substantial support and investment for the transition of the laboratory innovation to the practice, especially those promising breakthroughs in clinical applications [12].

The unique physicochemical properties of nanomaterials attractive for clinical applications, have prompted the development of nanomedicine and these properties also influence the behaviors of nanomedicine in the body $[13,14]$. The authors previously discussed the impacts of nanomaterials properties (size, shape, surface, et al.) on the metabolism of nanomaterials including circulation, organ-specific extravasation and clearance in vivo, which highlighted the flexible and controllable manipulation of the nanomaterials' behaviors by modulating their physicochemical properties [15]. Moreover, nano-scaled size endows nanomaterials with large surface areas and surface-hyperactivity, favorable for drug vectors. In the field of cancer nanomedicine research, biocompatible nanoparticles, such as liposomes and biodegradable polymers, can be loaded with conventional chemotherapeutic drugs, especially those with low solubility, to achieve a controlled drug release profile [16]. Nanovectors facilitate the biodistribution of drugs and improve the bioavailability. The encapsulation efficiency of nanoparticles can be optimized by controllable components and formulation parameters $[17,18]$. Due to their small sizes, these nanovectors carrying anti-cancer drugs could penetrate into the tissue and passively target tumor tissues by the enhanced permeability and retention (ERP) effect [19]. Recently, great progress has been made in the blood-brain barrier-crossing nanotechnology, and multifunctional nanoplatforms have been constructed to provide highly efficient brain cancer theranostics [20]. Furthermore, nanomaterials have been reported to effectively reverse tumor resistance compared to conventional cytotoxic drugs by stimulating the endocytosis of drug-resistant cells or prohibiting drug efflux with an increase in the drug therapeutic concentration [21]. The constructed nano-drug delivery platforms by mesoporous silica nanoparticles, carbon nanotubes and calcium phosphate nanoparticles, etc. exhibited an enhanced efficiency in delivering the therapeutic agents to desired tumors sites [22]. Large surface areas and surface hyperactivity make nanoparticles apt to surface modifications. By conjugating with the specific tumor markers on the surface of nanovehicles, target delivery of anti-cancer drugs can be realized. A typical example is theranostic nanoparticles which are usually externally-conjugated with antibody and polymers for targeting purposes, and internally-loaded with different bioactive molecules (nucleic acids, imaging contrast agents, etc.) for functional purposes [23,24].

Among these diversified nanomaterials, functionalized fullerenes have attracted substantial attention owing to their various functions in cancer diagnosis and therapy [25]. Their empty interior cavity allows the encapsulation of metal atoms, thus assisting in realizing the electronic basis needed for magnetic resonance imaging (MRI). However, the unique chemical structure renders fullerene to readily generate ROS by light exposure, offering the basis for photodynamic therapy [26,27]. More recently, a novel amine group-modified fullerene derivative (C70-(EDA)8) was reported to have the potential to fight against superbacteria owing to its unique electrostatic and hydrophobic interactions with the membrane of multidrug-resistant superbacteria [28]. The studies by Wang et al. demonstrated that gadofullerenol $(\mathrm{C} 70-\mathrm{OH})$ nanoparticles could alleviate the acute lung injury 
by simultaneously scavenging free radicals and modulating pulmonary fibrosis-associated TGF $\beta$ signaling [29]. More interestingly, C60-carboxyfullerene has been reported to act as peroxidase mimetics and monitor the glucose level in serum [30]. Therefore, the family of fullerenes possesses diversified medical functions and has shown great promise in biomedical applications.

$\mathrm{Gd}_{\mathrm{C}} \mathrm{C}_{82}(\mathrm{OH})_{22}$, a novel metallofullerenol first reported by our group, has been demonstrated to possess an efficient anti-tumor activity with free-carry of other anti-cancer drugs. Further, substantial studies by other scientists also confirmed the anti-tumor potentials of Gd-metallofullerenol [31,32]. More importantly, no obvious toxicity has been observed in animal model experiments, which can be attributed to the fact that $\mathrm{Gd}_{0} \mathrm{C}_{82}(\mathrm{OH})_{22}$ inhibited tumors by imprisoning rather than poisoning the tumor cells. $\mathrm{Gd} @ \mathrm{C}_{82}(\mathrm{OH})_{22}$ has shown great potential to resolve the direct cytotoxicity facing traditional chemotherapy. However, tumor encaging by $\mathrm{Gd} @ \mathrm{C}_{82}(\mathrm{OH})_{22}$ also suggests its great advantages as a neoadjuvant therapy, which has caused increasing attention in clinical practice. Neoadjuvant therapy, usually as a preoperative strategy, has been widely adopted in the treatment of various cancers [33-35]. Especially for certain cancer types with highly-metastatic potentials, the adoption of surgery probably receives unsatisfactory outcomes in clinical settings. Encaging tumor by $\mathrm{Gd}_{\mathrm{C}} \mathrm{\textrm {C } _ { 8 2 }}(\mathrm{OH})_{22}$ treatment in advance of surgery is speculated to greatly increase the operability of surgery and improve prognosis. Herein, $\mathrm{Gd} @ \mathrm{C}_{82}(\mathrm{OH})_{22}$ may be an attractive option for neoadjuvant therapy against tumors. In summary, tumor encaging by $\mathrm{Gd}_{0} \mathrm{C}_{82}(\mathrm{OH})_{22}$ is of great clinical significance.

\section{2. $\mathrm{Gd} @ \mathrm{C}_{82}(\mathrm{OH})_{22}$ as a Novel Anti-Tumor Drug Candidate}

\subsection{Physicochemical Characteristics of $\mathrm{Gd}_{0} \mathrm{C}_{82}(\mathrm{OH})_{22}$}

Gd@ $\mathrm{C}_{82}(\mathrm{OH})_{22}$ is a novel endohedral metallofullerenol compound with a unique structure and surface characteristics. Structurally, the $\mathrm{Gd}$ atom is encapsulated in a $\mathrm{C}_{82}$ carbon cage and the surface of carbon cage is modified with approximately 22 hydroxyl groups [36]. Hydroxyl groups are distributed asymmetrically on the carbon cage [37]. The biased distribution of hydroxyl groups on one side of carbon cage induces more exposure of the hydrophobic carbon cage on the other side. Thus, a single $\mathrm{Gd} @ \mathrm{C}_{82}(\mathrm{OH})_{22}$ molecule exhibits amphipathicity with hydrophilic $\mathrm{OH}$ groups and hydrophobic cage surface. However, considering that only one fourth of the carbon atom is functionalized with hydroxyl groups, the $\mathrm{Gd} @ \mathrm{C}_{82}(\mathrm{OH})_{22}$ molecule is largely hydrophobic. Thus, $\mathrm{Gd}_{0} \mathrm{C}_{82}(\mathrm{OH})_{22}$ molecules tend to aggregate into clusters with the hydration diameter of $70 \mathrm{~nm}$ in water or PBS. The formed clusters have been stable, as shown by a single peak size distribution in a physiological medium using dynamic light scattering analysis [38].

Furthermore, the polyhydroxylation of metallofullerenes can direct the electron transfer between the innermost $\mathrm{Gd}$ and the outer carbon cage, making the outer carbon cage negatively-charged and the inner Gd positively-charged [37]. Thus, the charge distribution of $\mathrm{Gd}_{0} \mathrm{C}_{82}(\mathrm{OH})_{22}$ may influence its interactions with biomolecules which have differently-charged residues protruding on the surfaces.

\subsection{Anti-Tumor Activity with High Efficiency and Low Toxicity}

$\mathrm{Gd} @ \mathrm{C}_{82}(\mathrm{OH})_{22}$ has been intensively investigated ranging from chemical synthesis, property investigation, biological effects and the potential safety concerns $[36,38,39]$. It has been demonstrated to inhibit tumor growth and metastasis with high efficiency and low toxicity in vitro and in vivo [40-42].

In the mice subcutaneously implanted with $\mathrm{H} 22$ hepatoma cells, $\mathrm{Gd} @ \mathrm{C}_{82}(\mathrm{OH})_{22}$, administrated by intraperitoneal injections, inhibited tumor growth much more efficiently than the conventional first-line chemotherapeutics. $\mathrm{Gd} @ \mathrm{C}_{82}(\mathrm{OH})_{22}$ showed a comparable efficiency in inhibiting tumor growth as cyclophosphamide that was used at a 20 times higher dosage [26]. Similarly, in the nude mice bearing breast cancer, the dosage of $\mathrm{Gd}_{0} \mathrm{C}_{82}(\mathrm{OH})_{22}$ used to achieve a comparable tumor inhibition was just one third of the paclitaxel dosage [36]. In addition to tumor growth suppression, $\mathrm{Gd}_{0} \mathrm{C}_{82}(\mathrm{OH})_{22}$ was also found to inhibit tumor metastasis. As shown in a tumor invasion model, a continuous 6-week treatment of $\mathrm{Gd}_{0} \mathrm{C}_{82}(\mathrm{OH})_{22}$ significantly prevented the translocation of breast cancer cells 
(MDA-MB-231) and the consequent tumor metastasis, whereas the establishment of tumor foci were apparently observed in the saline-treated control mice [43].

Apart from efficacy, the potential toxicity of drug candidates is viewed as another important determinant factor that governs clinical applications. Excitingly, $\mathrm{Gd}_{\mathrm{C}} \mathrm{C}_{82}(\mathrm{OH})_{22}$ induced no obvious toxicity, quite distinct from the conventional chemotherapeutic agents. First, $\mathrm{Gd} @ \mathrm{C}_{82}(\mathrm{OH})_{22}$-treated mice survived well with no animal deaths occurring, while the paclitaxel- and saline-treated groups had animal deaths. Second, $\mathrm{Gd} @ \mathrm{C}_{82}(\mathrm{OH})_{22}$-treated mice had undetectable weight alterations compared with the obvious weight loss in paclitaxel-treated mice. Third, paclitaxel treatment worsened tumor-induced nephrotoxicity marked by irreversible glomerulitis and cell necrosis. Instead, $\mathrm{Gd} @ \mathrm{C}_{82}(\mathrm{OH})_{22}$ induced no toxicity in important organs and even alleviated tumor-induced damage in kidney functions [27,42]. Last, no cytotoxicity was induced during testing by $\mathrm{Gd}_{0} \mathrm{C}_{82}(\mathrm{OH})_{22}$ in a variety of cell lines, including normal cells and tumor cells.

Therefore, $\mathrm{Gd} @ \mathrm{C}_{82}(\mathrm{OH})_{22}$, with a much lower dosage, exhibited a comparable tumor inhibition to the conventional chemotherapeutic drugs with marginal side effects, indicating the overwhelming advantages of $\mathrm{Gd} @ \mathrm{C}_{82}(\mathrm{OH})_{22}$ as a promising anti-tumor drug candidate.

\subsection{A Novel Anti-Tumor Mechanism by $\mathrm{Gd}_{82}(\mathrm{OH})_{22}$ : Encaging Tumors}

To date, anti-tumor multi-mechanisms have been identified for $\mathrm{Gd}_{\mathrm{C}} \mathrm{C}_{82}(\mathrm{OH})_{22}$ including immune modulation [44,45], ROS scavenging [46], angiogenesis inhibition [42], fibroblast deactivation [47], iron uptake inhibition [48], the suppression of cancer stem cells [49] and tumor imprisonment or encaging [43]. Among these mechanisms, tumor encaging is a novel mechanism first reported by our group. In the mice implanted with human breast cancer cells, a thick fibrous layer on tumor surface was formed in $\mathrm{Gd}_{0} \mathrm{C}_{82}(\mathrm{OH})_{22}$-treated mice. The thickness of the dense connective tissue surrounding the tumor was determined to be $450 \mu \mathrm{m}$. Conversely, a natural tumor extracellular matrix with an average thickness of $60 \mu \mathrm{m}$ was formed at the tumor boundary in saline-treated control mice (Figure 1a). Moreover, the fibrous layer was undetectable in other organs, suggesting that the formation of fibrous layer induced by $\mathrm{Gd} @ \mathrm{C}_{82}(\mathrm{OH})_{22}$ treatment was limited to tumor tissue with the absence of the general fibrosis [42]. The authors postulated that the formed thick fibrous cage may encapsulate cancer tissue, and the communications between the cancer and surrounding tissues was cut so that the tumor was imprisoned. A sketch of tumor encaging by $\mathrm{Gd}_{\mathrm{C}} \mathrm{C}_{82}(\mathrm{OH})_{22}$ is depicted in Figure $1 \mathrm{~b}$. Imprisoning rather than directly poisoning tumor cells accounted for the low toxicity of $\mathrm{Gd}_{\mathrm{C}} \mathrm{C}_{82}(\mathrm{OH})_{22}$ in anti-tumor effects, at least partially. 
a

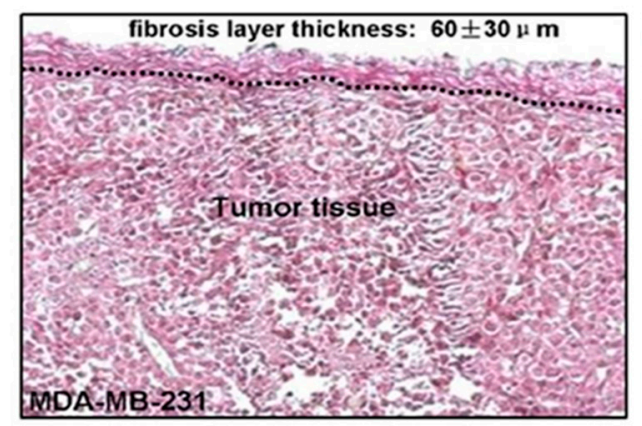

b

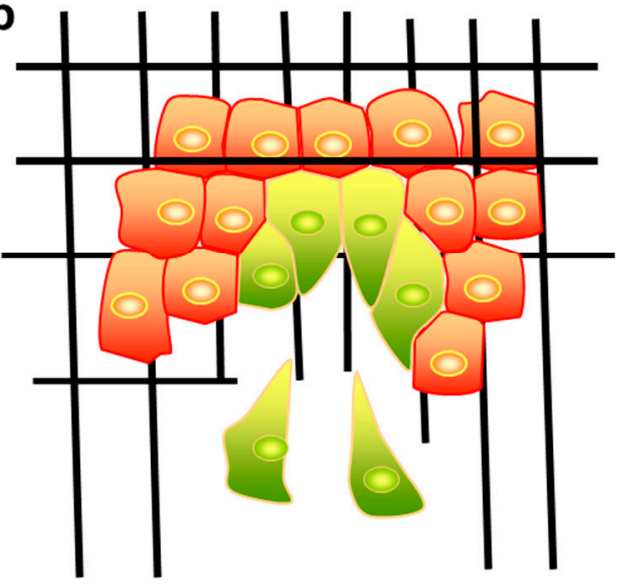

Tumor Jailbreak
$\mathrm{Gd} @ \mathrm{C}_{82}(\mathrm{OH})_{22}$ Therapy
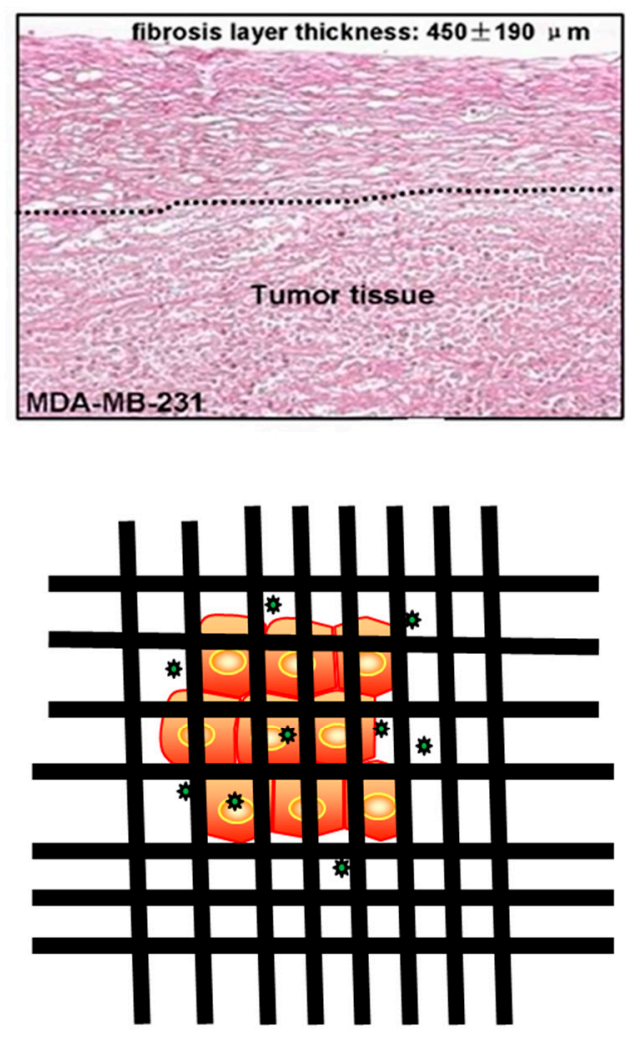

Tumor Encaging

Figure 1. Tumor encaging by $\mathrm{Gd} @ \mathrm{C}_{82}(\mathrm{OH})_{22}$ therapy. (a) Histological images of tumor tissues excised from Gd@ $\mathrm{C}_{82}(\mathrm{OH})_{22}$-treated mice and the saline control mice. The tumor tissues from control (Left) and $\mathrm{Gd} @ \mathrm{C}_{82}(\mathrm{OH})_{22}$-treated (Right) MDA-MB-231 xenograft mice; A thicken fibrosis layer surrounding tumor tissues was formed in $\mathrm{Gd}_{\mathrm{C}} \mathrm{C}_{82}(\mathrm{OH})_{22}$-treated animals. Reproduced with permissions from Meng, $\mathrm{H}$, Nanomedicine; published by Elsevier Inc. 2012. (b) A sketch for tumor encaging by $\mathrm{Gd} @ \mathrm{C}_{82}(\mathrm{OH})_{22}$. Tumor jailbreak (Left). The tumor cells secrete a large amount of matrix metalloproteinases (MMPs) to degrade the extracellular matrix and realize self-escape. $\mathrm{Gd}_{0} \mathrm{C}_{82}(\mathrm{OH})_{22}$ therapy inhibits tumor invasiveness and metastasis by tumor encaging (Right) ( represents $\mathrm{Gd} @ \mathrm{C}_{82}(\mathrm{OH})_{22}$ molecule).

\subsection{Molecular Mechanism of Tumor Encaging: MMP Inactivation and Collagen Stabilization}

As described in Figure 2, MMP deactivation and collagen stabilization contributed to tumor encaging by $\mathrm{Gd} @ \mathrm{C}_{82}(\mathrm{OH})_{22}$. On the one hand, $\mathrm{Gd} @ \mathrm{C}_{82}(\mathrm{OH})_{22}$ inhibited the matrix-degrading function of MMPs and thus prevented the proteolytic degradation of extracellular matrix in tumor progression [42]. On the other hand, $\mathrm{Gd}_{0} \mathrm{C}_{82}(\mathrm{OH})_{22}$ acted as a bridge to facilitate the formation of collagen oligomers or microfibrils, inducing the enhanced stability and rigidity of collagen layers.

By molecular-dynamics simulations, the interactions of $\mathrm{Gd}_{0} \mathrm{C}_{82}(\mathrm{OH})_{22}$ with MMPs and collagen were investigated. $\mathrm{Gd}_{0} \mathrm{C}_{82}(\mathrm{OH})_{22}$ was found to inhibit MMP-9 functions in an exosite way by allosteric regulation rather than targeting the zinc-binding active sites. Before approaching MMP-9, $\mathrm{Gd}_{\mathrm{C}} \mathrm{C}_{82}(\mathrm{OH})_{22}$ clustered and formed a trimer step by step relying on molecular interactions. Owing to the negative electric field that formed around the zinc-binding sites, the negatively-charged carbon cages were repelled, thus impeding the bindings to zinc-binding active sites. The negatively-charged carbon cages were guided to approach MMP-9 by two positively-charged residues (Lys 433 and Arg 440) via long-range electrostatic interactions, allowing the initial contact of $G d @ C_{82}(O H)_{22}$ with MMP-9. Afterwards, this interaction between $\mathrm{Gd} @ \mathrm{C}_{82}(\mathrm{OH})_{22}$ clusters and these two residues were facilitated by the formation of hydrogen bonds between the hydroxyl groups on carbon cages and the 
basic groups of residues. Following this, the hydrophobic interactions occurred between the largely hydrophobic surface of $\mathrm{Gd} @ \mathrm{C}_{82}(\mathrm{OH})_{22}$ and the hydrophobic residues exposed on the surface of the MMP-9 molecule. Finally, Gd@ $\mathrm{C}_{82}(\mathrm{OH})_{22}$ stably bound the sites near the $\mathrm{S} 1$ ligand specificity loop and SC loop by a combination of both specific electrostatic and hydrophobic interactions, probably prohibiting the substrate entry into the S1 ligand specificity loop [50]. Therefore, it seemed that the inhibition mode of MMP-9 by $\mathrm{Gd} @ \mathrm{C}_{82}(\mathrm{OH})_{22}$ was quite distinctive, depending on the unique physicochemical characteristics of $\mathrm{Gd} @ \mathrm{C}_{82}(\mathrm{OH})_{22}$.

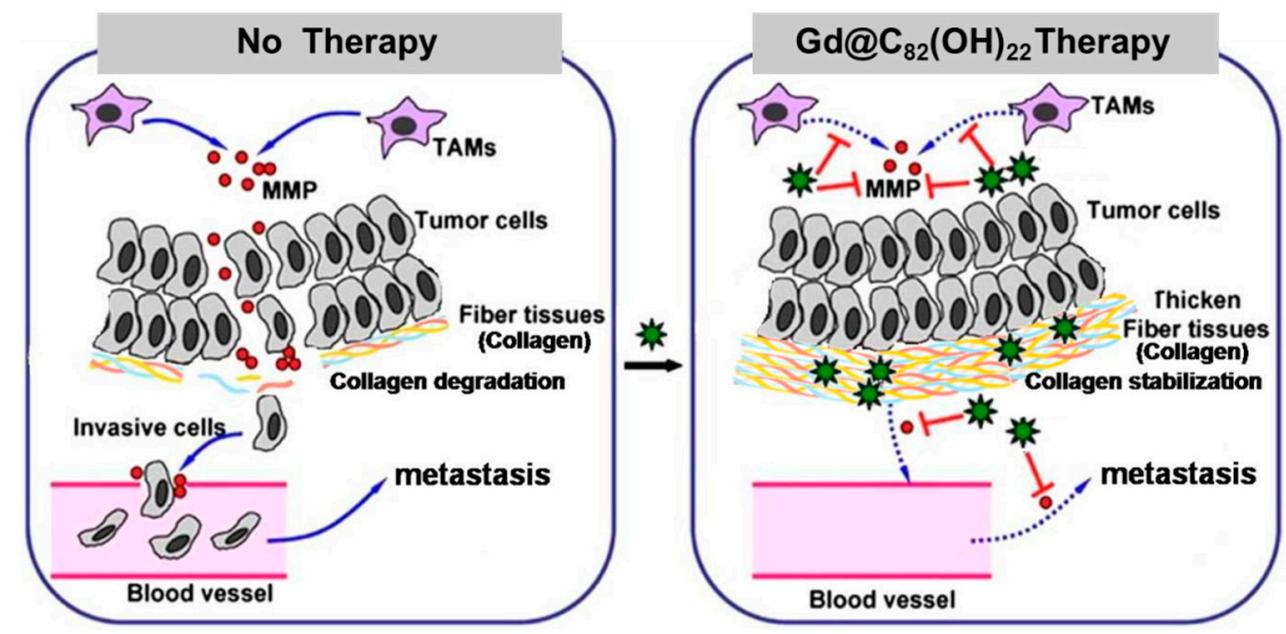

Figure 2. Schematic presentation of tumor encaging by $\mathrm{Gd} @ \mathrm{C}_{82}(\mathrm{OH})_{22}$. Instead of directly poisoning tumor cells, $\mathrm{Gd} @ \mathrm{C}_{82}(\mathrm{OH})_{22}$ encaged tumor via MMP inhibition and collagen stabilization. In the control mice (left panel), MMP secreted by tumor-associated macrophages (TAMs) efficiently degraded the collagen-consisting fibrous matrices. Consequently, tumor cells escaped and tumor metastasis occurred. In $\mathrm{Gd} @ \mathrm{C}_{82}(\mathrm{OH})_{22}$-treated mice (right panel), $\mathrm{Gd} @ \mathrm{C}_{82}(\mathrm{OH})_{22}$ decreased MMP production and activity and furthermore stabilized collagen by facilitating the formation of collagen microfibrils. The formed thick fibrous layers imprisoned tumor cells and the tumor failed to metastasize. ( represents $\mathrm{Gd} @ \mathrm{C}_{82}(\mathrm{OH})_{22}$ molecule). Adapted with permissions from Meng, H, Nanomedicine; published by Elsevier Inc. 2012.

As known, collagens, as one of major ECM components, are also tightly related with tumor progression [51]. Their expression, proteolysis and assembly all influence cellular functions to elicit multiple effects on tumors [52]. $\mathrm{Gd} @ \mathrm{C}_{82}(\mathrm{OH})_{22}$ has been reported to adhere to and interact with collagen molecules principally depending on the interaction of hydrogen bonds. The negatively-charged carbon cage was more preferentially bound to the positively-charged $\mathrm{N}$-terminus of collagen peptide chains where the strong electrostatic interactions happened with the largest number of the adhering $\mathrm{Gd} @ \mathrm{C}_{82}(\mathrm{OH})_{22}$ molecules. After adhering on the surface of collagen peptide chains, the hydrogen bonds formed between $\mathrm{Gd} @ \mathrm{C}_{82}(\mathrm{OH})_{22}$ and collagen peptide chains, thus facilitating the stability of the collagen triplex structure. Furthermore, $\mathrm{Gd} @ \mathrm{C}_{82}(\mathrm{OH})_{22}$ promoted the formations of collagen oligmers and microfibrils by hydrogen bonds' interaction with multiple polypeptide chains of collagen triplex, which the authors called fullerenol-mediated bridge [53]. Therefore, by electrostatic or hydrogen bonds interaction with collagen molecules, $\mathrm{Gd} @ \mathrm{C}_{82}(\mathrm{OH})_{22}$ stuck and stabilized the collagen molecules, rendering collagen less susceptible to degradation by MMPs. $\mathrm{Gd}_{8} \mathrm{C}_{82}(\mathrm{OH})_{22}$-induced collagen crosslinking provided another basis for the thicken fibrous layers formed surrounding the tumor tissues. 


\section{An Inspiration for Novel Drug Design: The Advantages of Nanomedicine}

\subsection{Exploitation of Tumor Imprisonment: The Development of MMP Inhibitors}

As known, both tumor growth and metastasis are largely dependent on the remodeling of the extracellular matrix which serves as physical supports to confine tumor cells [54,55]. To perform a jailbreak, tumor cells produce and secrete a large amount of matrix-cleaving enzymes directly. More often, stromal cells, such as tumor-associated fibroblasts, are recruited by the tumor and assist tumor cells to escape by secreting MMPs [56]. MMPs assist the tumor to cleave the surrounding extracellular matrix. Thus tumor cells escape from ECM imprisonment and finally invade other tissues more malignantly. Accumulating evidence has highlighted the tight associations between high-level MMPs and tumor malignancy [57,58]. In tumor tissues, MMPs are usually up-regulated, advantageous to tumor growth and metastasis [59]. Hence, MMPs are believed to hold the promise as molecular target of cancer therapy.

\subsection{Failure of Broad-Spectrum MMP Inhibitors: The Dilemma of Classical Drug Design}

Preventing ECM degradation by MMPs is considered as a new route to fight cancer. In the past two decades, many pharmaceutical companies have made great efforts to develop many MMP inhibitors [60]. Unexpectedly, these MMP inhibitors were disappointing in clinical trials, either with no efficacy or with severe adverse reactions [61]. The key reason for the failure lies in the lack of selectivity towards the specific MMPs by the designed MMP inhibitors [62]. In fact, the substrates of these MMPs are much more than extracellular matrix and different MMP isoforms play diversified roles in different stages of the tumor [63]. By proteolysis, some of the MMP isoforms can activate growth factors, for instance, angiostatin that inhibits tumor angiogenesis and metastasis [64]. The broad-spectrum MMP inhibitors target all MMPs, even those tumor-suppressing MMP members. This tribulation calls for a new generation of MMP inhibitors with enhanced selectivity and specificity. However, chemically, it is challenging to design the highly specific MMP inhibitors due to high similarities in MMPs' active sites. In fact, low selectivity is very common to small-molecular drugs which are traditionally designed according to the key and lock principle [65]. The key and lock principle, firstly put forward based on the model for enzyme-substrate interaction, mainly focuses on the active sites of enzymes. The specific complementary geometric shapes are suggested to be possessed by enzyme and substrate. Like a key into a lock, only the correct size and shape of the substrate (the key) could fit into the active site (the keyhole) of the enzyme (the lock). Following this, the key and lock principle extends its application to drug design. The designed small molecule drugs, with the correct geometric shapes and chemical properties, occupy the active sites and impact the function of biomolecules and ultimately disturb the associated biological process [66]. Despite the success in conducting the development of some molecule-targeted drugs, this canonical principle also encounters the dilemma where off-target occurred or low selectivity is very common. By strong chemical bonds, the interaction between small-molecular drugs and the active sites, in most instances, is compounded by the presence of high similarities in active sites possessed by a family of proteins and generated indiscriminate inhibitions. Therefore, a new strategy of drug design is urgently expected.

\subsection{Action Mode of $\mathrm{Gd}_{\mathrm{C}} \mathrm{C}_{82}(\mathrm{OH})_{22}$ Towards Key Biomolecules: The Advantages of Nanomedicine}

The structure-activity relationship where the structures of drug molecules affect their interactions with biomolecules and the sequent biological functions is widely recognized as the basis of drug design [67]. The structure-activity relationship should be elaborated when it comes to discussions on the advantages of nanomedicine:

First, the chemical structure impacts the stability of nanomedicine and the physiochemical properties. The authors previously discussed the impacts of surface-chemical design on physiochemical properties and biological effects of various carbon nanomaterials including carbon nanotubes, graphenes, fullerenes, metallofullerenes and their derivatives in detail. The reader may refer to 
Ref [37]. Our present discussion will be focused on metallofullerenols. The chemical modification on metallofullerene surface is highly related with the opening of unsaturated double bonds on the carbon cage and the addition of chemical groups onto the surface. Thus, to maintain the stability and integrity of carbon cage, the number of added chemical groups has to be controlled. For multihydroxylated fullerene, the total number of modified groups on the cage surface should be controlled in order not to destroy the carbon cage arising from the strong interaction between the neighboring hydroxyls. The modification of 22 hydroxyl group with $-\mathrm{OH}$ number varying in \pm 2 , was verified to have a favorable chemical stability.

Apart from the impacts on the structural stability, the surface chemistry of fullerene cage can also modulate the electronic configuration of the encaged metallic atoms inside a nanospace and the electron donation directions, thus influencing the electronic and magnetic properties of metallofullerene. Using synchrotron X-ray photoelectron spectroscopy, the authors previously investigated the modulations of electronic configurations of the innermost $\mathrm{Gd}$ atoms inside different nanospaces provided by $\mathrm{Gd}_{\mathrm{C}} \mathrm{C}_{82}, \mathrm{Gd}_{\mathrm{C}} \mathrm{C}_{82}(\mathrm{OH})_{12}, \mathrm{Gd}_{\mathrm{C}} \mathrm{C}_{82}(\mathrm{OH})_{22}$. A sandwich-type electronic interaction occurred in a synergistic manner along the pathways. The cage modification, group-cage, surfaced the innermost metallic atom [68]. The hydroxyl number also affected the electronic properties and electron-transfer direction $[37,69]$. The electron emission showed a periodical variation depending on the number of added hydroxyl groups on the outer cage surface. It provides a possibility to control electronic donation direction by surface chemical modifications [68].

As previously discussed, both the number of modified groups and their distribution patterns on the outer carbon surface are the key factors determining the modulation of nanomaterial structures and the corresponding properties of fullerene derivatives. The multihydroxylation increased the solubility of $\mathrm{Gd} @ \mathrm{C}_{82}(\mathrm{OH})_{22}$ in water. The nanosize and the more hydrophobicity rendered $\mathrm{Gd}_{0} \mathrm{C}_{82}(\mathrm{OH})_{22}$ readily to aggregate with the size of $22 \mathrm{~nm}$. The structure of $\mathrm{Gd}_{\mathrm{C}} \mathrm{C}_{82}(\mathrm{OH})_{22}$, as stated above, allows the formation of hydrogen bonds and hydrophobic interaction, respectively. The negatively-charged carbon cage tends to cause electronic interaction with the positively-charged molecules.

Second, the structure of nanomedicine affects its interactions with biomolecules. The interaction modes of nanomedicine with biomolecules can be manipulated by nano-scaled size and the controllable chemical modifications, which probably endow drug designs with high feasibility and flexibility. While different from the small-molecular drugs interacting with target molecules via strong chemical bonds, nanomedicine interacts with different biomolecules in a much milder and weaker manner, mainly via electrostatic, hydrophobic and specific hydrogen-bonding interactions. These interactions may direct nanoparticles to cluster into different shapes and guide the binding of nanoparticles to the specific surface region of biomolecules, making nanoparticles target-tailoring. As active sites are often conservative in a biomolecule family, regulatory domains usually bearing a much lower similarity, tend to be a more promising alternative for the drug design. $\mathrm{Gd} @ \mathrm{C}_{82}(\mathrm{OH})_{22}$ inhibited MMP-9 mainly via allosteric regulation of an exocite interaction with little involvement of the well-known zinc catalytic site [50]. Gd@ $\mathrm{C}_{82}(\mathrm{OH})_{22}$ interacted with the approaching biomolecules MMP-9 or collagen depending on different cage positions to contact with certain biomolecules. The interactions of $\mathrm{Gd}_{\mathrm{C}} \mathrm{C}_{82}(\mathrm{OH})_{22}$ with other biomolecules also provide support for this specific action mode of $\mathrm{Gd}_{\mathrm{C}} \mathrm{C}_{82}(\mathrm{OH})_{22}$ based on its unique structural characteristics [70-72]. Figure 3 demonstrates the results on molecular dynamics of $\mathrm{Gd} @ \mathrm{C}_{82}(\mathrm{OH})_{22}$ interacting with key ECM-associated biomolecules including collagen, MMP-9 and MMP-2, indicating the selective and specific binding mode of $\mathrm{Gd}_{\mathrm{C}} \mathrm{C}_{82}(\mathrm{OH})_{22}$ with biomolecules. Recently, Zhou et al. substituted a new functional group, $\mathrm{PO}_{4}^{2-\text {, }}$ for a hydroxyl group on the fullerenol surface of $\mathrm{Gd} @ \mathrm{C}_{82}(\mathrm{OH})_{22}$ and then found that $\mathrm{Gd} @ \mathrm{C}_{82}(\mathrm{OH})_{21}\left(\mathrm{PO}_{4}\right)^{2-}$ bound more strongly to MMP-9 than $\mathrm{Gd}_{0} \mathrm{C}_{82}(\mathrm{OH})_{22}$ [73]. More importantly, it is worth emphasizing that the favorable weak interactions may still maintain the native fold of target proteins, which accounts for the slight toxicity induced by MMP inhibition after $\mathrm{Gd}_{8} \mathrm{C}_{82}(\mathrm{OH})_{22}$ treatment. Contrary, the strong hydrophobic and aromatic stacking interactions of the single-wall carbon nanotubes (SWCNTs) was reported to destroy the protein hydrophobic core and tertiary structure, which led to obvious nanotoxicity [74]. Therefore, 
it can be tentatively inferred that the formed shape of nanoclusters and the contact parameters with biomolecules including the size of contact areas, the hydrophobic or hydrophilic contact sites and the intensity of interactions, can be manipulated by controlled particle sizes and surface modifications, which influences the binding specificity and selectivity toward certain target molecules.

\section{a Interaction with collagen $\quad$ b Interaction with MMP-2}
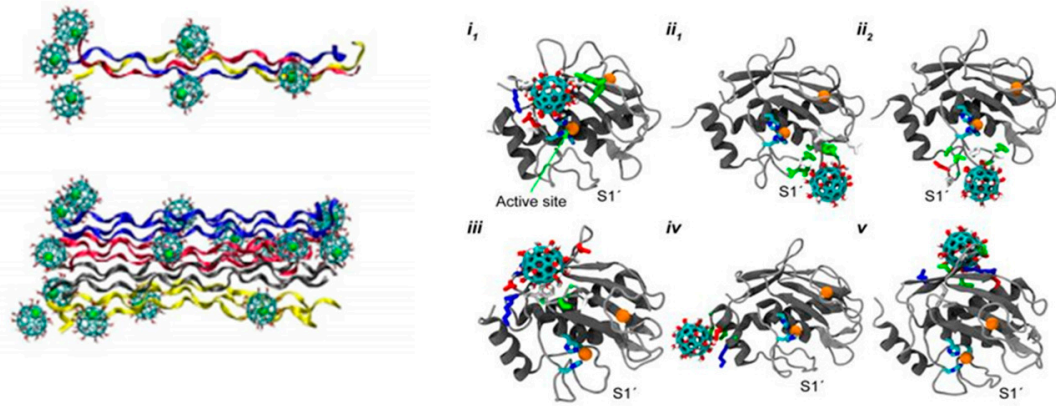

c
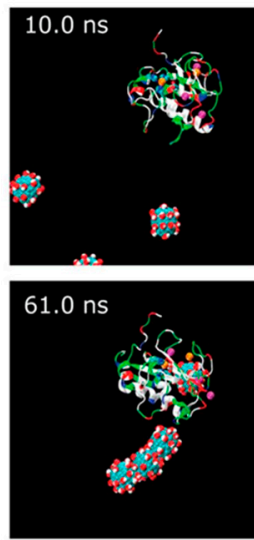

Interaction with MMP-9
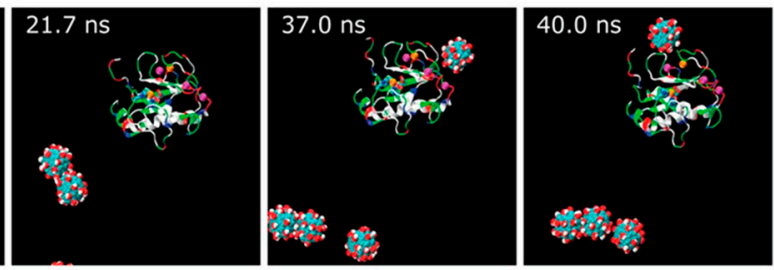

$78.5 \mathrm{~ns}$

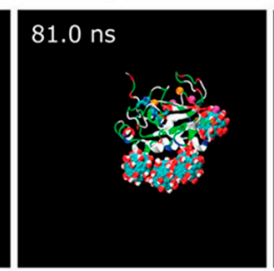

$95.5 \mathrm{~ns}$

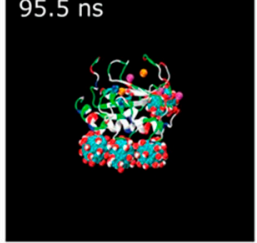

Figure 3. Molecular dynamics of $\mathrm{Gd}_{\mathrm{C}} \mathrm{C}_{82}(\mathrm{OH})_{22}$ interacting with key ECM-associated biomolecules. $\mathrm{Gd} @ \mathrm{C}_{82}(\mathrm{OH})_{22}$ could bind to collagen and MMPs step by step but differ in the binding modes. (a) $\mathrm{Gd} @ \mathrm{C}_{82}(\mathrm{OH})_{22}$ interacting with collagen molecules. $\mathrm{Gd} @ \mathrm{C}_{82}(\mathrm{OH})_{22}$-mediated bridge among collagen molecules greatly restricted their relative rotation and crosslinked collagen molecules [53]. (b) $\mathrm{Gd} @ \mathrm{C}_{82}(\mathrm{OH})_{22}$ interacting with MMP-2. $\mathrm{Gd} @ \mathrm{C}_{82}(\mathrm{OH})_{22}$ could block $\mathrm{Zn}^{2+}$-catalytic site directly or exocitely bind at the ligand specificity S1' loop [75]. (c) $\mathrm{Gd} @ \mathrm{C}_{82}(\mathrm{OH})_{22}$ interacting with MMP-9. $\mathrm{Gd} @ \mathrm{C}_{82}(\mathrm{OH})_{22}$ induced a specific binding with MMP-9 near the ligand-specificity S1' loop [50]. Reproduced with permissions from Yin. X.H, Nanoscale; published by The Royal Society of Chemistry, 2013. Kang S.G, Scientific reports; published by Nature Publishing Group, 2014. Kang S.G, Proceedings of the national academy of sciences; published by Natl Acad Sciences, 2012.

Third, the structure of nanomaterials is a key determinant factor in the biological effects of nanomaterials. Previously, the authors compared the toxicity of $\mathrm{Gd} @ \mathrm{C}_{82}(\mathrm{OH})_{22}$ and other carbon nanomaterials to illustrate the role of the structure in determining biological effects. For example, after respiratory exposure to the single-wall carbon nanotubes (SWCNTs) for $72 \mathrm{~h}$, the spontaneously hypertensive rats developed pulmonary inflammation and peripheral vascular thrombosis [76]. Carbon nanotubes were observed to destroy the membranes of human gut bacteria [77]. Moreover, the cytotoxicity of carbon nanomaterials with different structures was compared, including single-wall nanotubes (SWNTs), multi-wall nanotubes (MWNTs) and fullerene $\left(\mathrm{C}_{60}\right)$ on alveolar macrophages, and $\mathrm{C}_{60}$ was found to induce the smallest cytotoxicity [78]. Later, the biological effects of fullerene derivatives $\mathrm{Gd} @ \mathrm{C}_{82}(\mathrm{OH})_{22}$ and $\mathrm{C}_{60}(\mathrm{OH})_{20}$ were compared, especially the anti-tumor activity. Resultantly, $\mathrm{C}_{60}(\mathrm{OH})_{20}$ was found to possess an attenuated anti-tumor activity compared 
with $\mathrm{Gd} @ \mathrm{C}_{82}(\mathrm{OH})_{22}$, which was finally tracked to the differences in the number and distribution pattern of hydroxyl groups on the carbon cage of these two different fullerene derivatives [79]. A smaller number of hydrogen bonds formation happened when $\mathrm{C}_{60}(\mathrm{OH})_{22}$ interacted with collagen peptide triplex. Compared with $\mathrm{C}_{60}(\mathrm{OH})_{22}, \mathrm{Gd}_{\mathrm{C}} \mathrm{C}_{82}(\mathrm{OH})_{22}$ had a smaller percentage of carbon atoms functionalized by hydroxyl groups and exposed more of the carbon cage surface, being more hydrophobic. The negatively-charged fullerenol cage facilitated the electrostatic interaction with collagen. The stronger hydrophobic and electrostatic interaction facilitated the absorption of $\mathrm{Gd}_{0} \mathrm{C}_{82}(\mathrm{OH})_{22}$ on collagen molecules, allowing a more favorable formation of hydrogen bonds with collagen molecules.

Due to the flexibility and diversity of interacting with certain molecules, nanomedicine, such as Gd@ $\mathrm{C}_{82}(\mathrm{OH})_{22}$, seems to be a transformable and dynamic key that could match several locks depending on the surface characteristics of the target biomolecules. In detail, the canonical key and lock principle requires the existence of the complementary geometric shapes between the molecular drug (the key) and the target biomolecules (the lock) to fit into the active site (the keyhole). If the molecular drug cannot match the active site of the target biomolecules, off-target happens and no drug efficacy generates. In contrast, designed nanomedicine could intelligently detect the surface characteristics and selectively interact with the unique surface area of target biomolecules, thus enhancing the target specificity. Depending on the surface characteristics of the target biomolecules, nanomedicine, just like a transformable and dynamic key, can self-assemble into suitable shapes to match several locks for thermodynamic stability, suggesting the target-tailoring ability of nanomedicine. Figure 4 demonstrates a brief history of MMP-based research from the discovery of the first MMP in 1962 [80], the consecutive identifications of MMP family members and their biological functions [81], the development of MMP inhibitors to novel MMP-inhibiting nanomedicine $\mathrm{Gd} @ \mathrm{C}_{82}(\mathrm{OH})_{22}$.

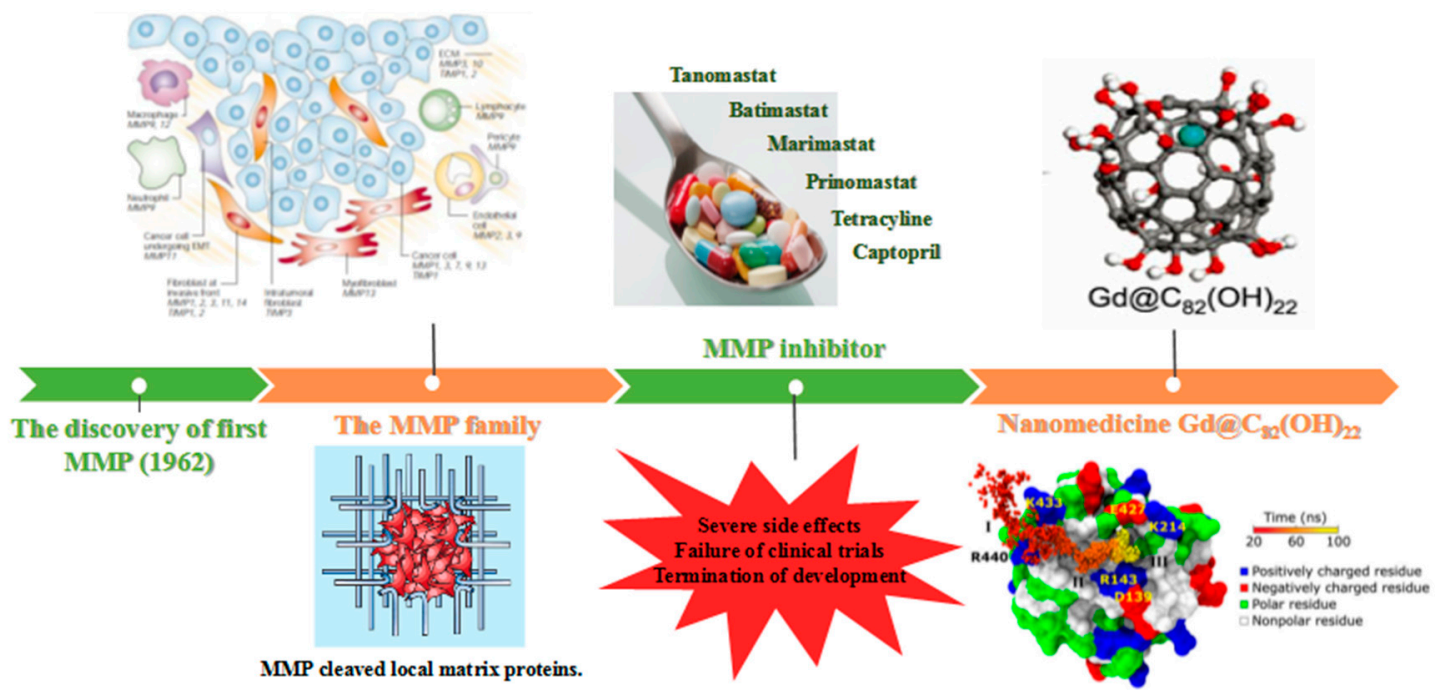

Figure 4. A brief history of MMP-based discovery: From MMP inhibitors to $G d @ C_{82}(O H)_{22}$. After the discovery of the first MMP in 1962 [80], the intercellular regulation of MMP family was also explored, particularly in tumor cells [56,81]. Subsequently, the development of MMP inhibitors was initiated to achieve tumor confinement. However, due to their low selectivity and severe side effects, these MMP inhibitors failed in clinical trials and drug development was abandoned. The emergence of $\mathrm{Gd} @ \mathrm{C}_{82}(\mathrm{OH})_{22}$ may bring the light for the development of selective MMP inhibitors owing to the unique physicochemical characteristics of nanomaterials [42,50]. The figure is constructed based on the above references. Adapted with permissions from Egeblad. M, Nature reviews cancer; published by Nature Publishing Group, 2002, Kang S.G, Proceedings of the national academy of sciences; published by Natl Acad Sciences, 2012. Yamada K.M, Nature; published by Nature Publishing Group, 2003. Meng H, ACS Nano; published by American Chemical Society, 2010. 


\section{Conclusions and Perspectives}

Despite being in its infancy, nanomedicine, due to its unique physical-chemical properties, holds great promise in the near future. As $\mathrm{Gd} @ \mathrm{C}_{82}(\mathrm{OH})_{22}$ starts the journey to clinical application, a new antineoplastic mechanism of imprisoning rather than poisoning the tumor has been uncovered, which may supply solutions for alleviating or conquering the toxicity faced by traditional chemotherapy. Furthermore, the action mode of nanoparticles with biomolecules has been revealed, implicating the de novo design of drugs and the potential of nanotechnology in revolutionizing the current strategy of drug design.

However, challenges also exist for $\mathrm{Gd}_{0} \mathrm{C}_{82}(\mathrm{OH})_{22}$ to step forward for clinical applications. The definite distribution analysis of hydroxyl groups on the carbon cage have to be identified. Moreover, the identification of metabolites after $\mathrm{Gd}_{0} \mathrm{C}_{82}(\mathrm{OH})_{22}$ entering the body is another important issue to be addressed, which reflects the behaviors of $\mathrm{Gd}_{0} \mathrm{C}_{82}(\mathrm{OH})_{22}$ in the body and influences its toxicological profile. In spite of the clinical challenges facing $\mathrm{Gd}_{0} \mathrm{C}_{82}(\mathrm{OH})_{22}, \mathrm{Gd}_{\mathrm{C}} \mathrm{C}_{82}(\mathrm{OH})_{22}$, as a promising novel anti-tumor nanomaterial, exhibited a highly-efficient antineoplastic activity with low toxicity based on numerous solid preclinical data. Enormous effort has to be made to translate $\mathrm{Gd} @ \mathrm{C}_{82}(\mathrm{OH})_{22}$ from a laboratory innovation to the clinic. Due to the advantages of nanotechnology, society will benefit from nanomedicine in the near future.

Author Contributions: All authors are approved this version to be submitted and promise that there is no potential conflict of interest.

Funding: This work was financially supported by National Natural Science Foundation of China (Project No. 21301176, 11305182)

Conflicts of Interest: The authors declare no conflicts of interest.

\section{References}

1. Siegel, R.L.; Miller, K.D.; Jemal, A. Cancer statistics, 2019. CA Cancer J. Clin. 2019, 69, 7-34. [CrossRef]

2. Siegel, R.; Naishadham, D.; Jemal, A. Cancer statistics, 2012. CA Cancer J. Clin. 2012, 62, 10-29. [CrossRef]

3. Bray, F.; Jemal, A.; Grey, N.; Ferlay, J.; Forman, D. Global cancer transitions according to the human development index (2008-2030): A population-based study. Lancet Oncol. 2012, 13, 790-801. [CrossRef]

4. Hannun, Y.A. Apoptosis and the dilemma of cancer chemotherapy. Blood 1997, 89, 1845-1853.

5. Coates, A.; Abraham, S.; Kaye, S.B.; Sowerbutts, T.; Frewin, C.; Fox, R.M.; Tattersall, M.H.N. On the receiving end-patient perception of the side-effects of cancer chemotherapy. Eur. J. Cancer Clin. Oncol. 1983, 19, 203-208. [CrossRef]

6. Shaffer, B.C.; Gillet, J.-P.; Patel, C.; Baer, M.R.; Bates, S.E.; Gottesman, M.M. Drug resistance: Still a daunting challenge to the successful treatment of AML. Drug Resist. Updat. 2012, 15, 62-69. [CrossRef]

7. Yuan, R.; Hou, Y.; Sun, W.; Yu, J.; Liu, X.; Niu, Y.; Lu, J.-J.; Chen, X. Natural products to prevent drug resistance in cancer chemotherapy: A review. Ann. N Y Acad. Sci. 2017, 1401, 19-27. [CrossRef]

8. Ren, F.; Shen, J.; Shi, H.; Hornicek, F.J.; Kan, Q.; Duan, Z. Novel mechanisms and approaches to overcome multidrug resistance in the treatment of ovarian cancer. Biochim. Biophys. Acta 2016, 1866, 266-275. [CrossRef]

9. Ren, Z.; Sun, J.; Sun, X.; Hou, H.; Li, K.; Ge, Q. Efficacy and safety of different molecular targeted agents based on chemotherapy for gastric cancer patients treatment: A network meta-analysis. Oncotarget 2017, 8, 48253-48262. [CrossRef]

10. Shah, C.P.; Moreb, J.S. Cardiotoxicity due to targeted anticancer agents: A growing challenge. Ther. Adv. Cardiovasc. Dis. 2019, 13, 1753944719843435. [CrossRef]

11. Zottel, A.; Videtic Paska, A.; Jovcevska, I. Nanotechnology meets oncology: Nanomaterials in brain cancer research, diagnosis and therapy. Materials (Basel) 2019, 12, 1588. [CrossRef]

12. Jia, L.; Zhao, Y.L.; Liang, X.J. Fast evolving nanotechnology and relevant programs and entities in China. Nano Today 2011, 6, 6-11. [CrossRef]

13. Minchin, R. Nanomedicine: Sizing up targets with nanoparticles. Nat nanotechnol 2008, 3, 12-13. [CrossRef]

14. Kawasaki, E.S.; Player, A. Nanotechnology, nanomedicine, and the development of new, effective therapies for cancer. Nanomedicine 2005, 1, 101-109. [CrossRef] 
15. Wang, B.; He, X.; Zhang, Z.; Zhao, Y.; Feng, W. Metabolism of nanomaterials in vivo: Blood circulation and organ clearance. Acc. Chem. Res. 2012, 46, 761-769. [CrossRef]

16. Ghosh, S.; Ghosh, S.; Sil, P.C. Role of nanostructures in improvising oral medicine. Toxicol. Rep. 2019, 6, 358-368. [CrossRef]

17. Han, S.; Liu, Y.; Nie, X.; Xu, Q.; Jiao, F.; Li, W.; Zhao, Y.; Wu, Y.; Chen, C. Efficient delivery of antitumor drug to the nuclei of tumor cells by amphiphilic biodegradable poly(L-aspartic acid-co-lactic acid)/DPPE co-polymer nanoparticles. Small 2012, 8, 1596-1606. [CrossRef]

18. Miao, Q.H.; Xu, D.X.; Wang, Z.; Xu, L.; Wang, T.W.; Wu, Y.; Lovejoy, D.B.; Kalinowski, D.S.; Richardson, D.R.; $\mathrm{Nie}, \mathrm{G} . J . ;$ et al. Amphiphilic hyper-branched co-polymer nanoparticles for the controlled delivery of anti-tumor agents. Biomaterials 2010, 31, 7364-7375. [CrossRef]

19. Maeda, H.; Bharate, G.Y.; Daruwalla, J. Polymeric drugs for efficient tumor-targeted drug delivery based on EPR-effect. Eur. J. Pharm. Biopharm. 2009, 71, 409-419. [CrossRef]

20. Tang, W.; Fan, W.; Lau, J.; Deng, L.; Shen, Z.; Chen, X. Emerging blood-brain-barrier-crossing nanotechnology for brain cancer theranostics. Chem. Soc. Rev. 2019, 48, 2967-3014. [CrossRef]

21. Ma, X.W.; Zhao, Y.L.; Liang, X.J. Nanodiamond delivery circumvents tumor resistance to doxorubicin. Acta Pharmacol. Sin. 2011, 32, 543-544. [CrossRef]

22. Naz, S.; Shamoon, M.; Wang, R.; Zhang, L.; Zhou, J.; Chen, J. Advances in therapeutic implications of inorganic drug delivery nano-platforms for cancer. Int. J. Mol. Sci. 2019, 20, 965. [CrossRef]

23. Ma, X.W.; Zhao, Y.L.; Liang, X.J. Theranostic nanoparticles engineered for clinic and pharmaceutics. Acc. Chem. Res. 2011, 44, 1114-1122. [CrossRef]

24. Li, J.X. Nanotechnology-based platform for early diagnosis of cancer. Sci. Bull. 2015, 60, 488-490. [CrossRef]

25. Wang, T.; Wang, C. Functional metallofullerene materials and their applications in nanomedicine, magnetics, and electronics. Small 2019, e1901522. [CrossRef]

26. Chen, C.; Xing, G.; Wang, J.; Zhao, Y.; Li, B.; Tang, J.; Jia, G.; Wang, T.; Sun, J.; Xing, L.; et al. Multihydroxylated $\left[\mathrm{Gd} @ \mathrm{C}_{82}(\mathrm{OH})_{22}\right]_{\mathrm{n}}$ nanoparticles: Antineoplastic activity of high efficiency and low toxicity. Nano Lett. 2005, 5, 2050-2057. [CrossRef]

27. Wang, J.; Chen, C.; Li, B.; Yu, H.; Zhao, Y.; Sun, J.; Li, Y.; Xing, G.; Yuan, H.; Tang, J.; et al. Antioxidative function and biodistribution of $\left[\mathrm{Gd} @ \mathrm{C}_{82}(\mathrm{OH})_{22}\right]_{\mathrm{n}}$ nanoparticles in tumor-bearing mice. Biochem. Pharmacol. 2006, 71, 872-881. [CrossRef]

28. Zhang, J.; Xu, J.; Ma, H.; Bai, H.; Liu, L.; Shu, C.; Li, H.; Wang, S.; Wang, C. Designing an Amino-Fullerene Derivative C70-(EDA) 8 to Fight Superbacteria. ACS Appl. Mater. Interfaces 2019, 11, 14597-14607. [CrossRef]

29. Zhou, Y.; Zhen, M.; Ma, H.; Li, J.; Shu, C.; Wang, C. Inhalable gadofullerenol/[70] fullerenol as high-efficiency ROS scavengers for pulmonary fibrosis therapy. Nanomedicine 2018, 14, 1361-1369. [CrossRef]

30. Li, R.; Zhen, M.; Guan, M.; Chen, D.; Zhang, G.; Ge, J.; Gong, P.; Wang, C.; Shu, C. A novel glucose colorimetric sensor based on intrinsic peroxidase-like activity of C60-carboxyfullerenes. Biosens. Bioelectron. 2013, 47, 502-507. [CrossRef]

31. Guan, M.; Zhou, Y.; Liu, S.; Chen, D.; Ge, J.; Deng, R.; Li, X.; Yu, T.; Xu, H.; Sun, D.; et al. Photo-triggered gadofullerene: Enhanced cancer therapy by combining tumor vascular disruption and stimulation of anti-tumor immune responses. Biomaterials 2019, 213, 119218. [CrossRef] [PubMed]

32. Zhou, Y.; Deng, R.; Zhen, M.; Li, J.; Guan, M.; Jia, W.; Li, X.; Zhang, Y.; Yu, T.; Zou, T.; et al. Amino acid functionalized gadofullerene nanoparticles with superior antitumor activity via destruction of tumor vasculature in vivo. Biomaterials 2017, 133, 107-118. [CrossRef] [PubMed]

33. Cain, H.; Macpherson, I.R.; Beresford, M.; Pinder, S.E.; Pong, J.; Dixon, J.M. Neoadjuvant Therapy in Early Breast Cancer: Treatment Considerations and Common Debates in Practice. Clin. Oncol. (R. Coll. Radiol.) 2017, 29, 642-652. [CrossRef] [PubMed]

34. Helmink B1, W.J. Neoadjuvant therapy for melanoma: Is it ready for prime time? Lancet Oncol. 2019, 19, 30377-30378. [CrossRef]

35. Assi, T.; El Rassy, E.; Farhat, F.; Kattan, J. Overview on the role of preoperative therapy in the management of kidney cancer. Clin. Transl. Oncol. 2019. [CrossRef] [PubMed]

36. Cheng, Y.; Liu, K.M.; Xing, G.M.; Yuan, H.; Jing, L.; Zhao, Y.L. Study of multihydroxylated processes of Gd@C 82 by ICP-MASS. J. Radioanal. Nucl. Ch. 2007, 272, 537-540. [CrossRef] 
37. Tang, J.; Xing, G.M.; Zhao, Y.L.; Jing, L.; Gao, X.F.; Cheng, Y.; Yuan, H.; Zhao, F.; Chen, Z.; Meng, H.; et al. Periodical variation of electronic properties in polyhydroxylated metallofullerene materials. Adv. Mater. 2006, 18, 1458-1462. [CrossRef]

38. Meng, J.; Liang, X.; Chen, X.; Zhao, Y. Biological characterizations of $\left[\mathrm{Gd} @ \mathrm{C}_{82}(\mathrm{OH})_{22}\right]_{\mathrm{n}}$ nanoparticles as fullerene derivatives for cancer therapy. Integr. Biol. 2013, 5, 43-47. [CrossRef]

39. Jiao, F.; Qu, Y.; Zhou, G.Q.; Liu, Y.; Li, W.; Ge, C.C.; Li, Y.F.; Hu, W.; Li, B.; Gao, Y.X.; et al. Modulation of oxidative stress by functionalized fullerene materials in the lung tissues of female C57/BL mice with a metastatic lewis lung carcinoma. J. Nanosci. Nanotechnol. 2010, 10, 8632-8637. [CrossRef]

40. Li, Y.; Tian, Y.; Nie, G. Antineoplastic activities of $\mathrm{Gd} @ \mathrm{C}_{82}(\mathrm{OH})_{22}$ nanoparticles: Tumor microenvironment regulation. Sci. Chin. Life Sci. 2012, 55, 884-890. [CrossRef]

41. Zhang, W.D.; Sun, B.Y.; Zhang, L.Z.; Zhao, B.L.; Nie, G.J.; Zhao, Y.L. Biosafety assessment of Gd@C $\mathrm{C}_{82}(\mathrm{OH})_{22}$ nanoparticles on Caenorhabditis elegans. Nanoscale 2011, 3, 2636-2641. [CrossRef] [PubMed]

42. Meng, H.; Xing, G.M.; Sun, B.Y.; Zhao, F.; Lei, H.; Li, W.; Song, Y.; Chen, Z.; Yuan, H.; Wang, X.X.; et al. Potent angiogenesis inhibition by the particulate form of fullerene derivatives. ACS Nano 2010, 4, 2773-2783. [CrossRef] [PubMed]

43. Meng, H.; Xing, G.M.; Blanco, E.; Song, Y.; Zhao, L.; Sun, B.; Li, X.; Wang, P.C.; Korotcov, A.; Li, W.; et al. Gadolinium metallofullerenol nanoparticles inhibit cancer metastasis through matrix metalloproteinase inhibition: Imprisoning instead of poisoning cancer cells. Nanomedicine 2012, 8, 136-146. [CrossRef] [PubMed]

44. Liu, Y.; Jiao, F.; Qiu, Y.; Li, W.; Lao, F.; Zhou, G.Q.; Sun, B.Y.; Xing, G.M.; Dong, J.Q.; Zhao, Y.L.; et al. The effect of $\mathrm{Gd} @ \mathrm{C}_{82}(\mathrm{OH})_{22}$ nanoparticles on the release of Th1/Th2 cytokines and induction of TNF- $\alpha$ mediated cellular immunity. Biomaterials 2009, 30, 3934-3945. [CrossRef] [PubMed]

45. Tang, J.; Chen, Z.; Sun, B.; Dong, J.; Liu, J.; Zhou, H.; Wang, L.; Bai, R.; Miao, Q.; Zhao, Y.; et al. Polyhydroxylated fullerenols regulate macrophage for cancer adoptive immunotherapy and greatly inhibit the tumor metastasis. Nanomedicine 2016, 12, 945-954. [CrossRef] [PubMed]

46. Yin, J.-J.; Lao, F.; Meng, J.; Fu, P.P.; Zhao, Y.L.; Xing, G.M.; Gao, X.Y.; Sun, B.Y.; Wang, P.C.; Chen, C.Y.; et al. Inhibition of tumor growth by endohedral metallofullerenol nanoparticles optimized as reactive oxygen species scavenger. Mol. Pharmacol. 2008, 74, 1132-1140. [CrossRef] [PubMed]

47. Tang, J.; Guo, M.; Wang, P.; Liu, J.; Xiao, Y.; Cheng, W.; Gao, J.; Hu, W.; Miao, Q.R. Gd-metallofullerenol nanoparticles cause intracellular accumulation of PDGFR- $\alpha$ and morphology alteration of fibroblasts. Nanoscale 2019, 11, 4743-4750. [CrossRef] [PubMed]

48. Li, J.; Xing, X.; Sun, B.; Zhao, Y.; Wu, Z. Metallofullerenol inhibits cellular iron uptake by inducing transferrin tetramerization. Chem. Asian J. 2017, 12, 2646-2651. [CrossRef]

49. Liu, Y.; Chen, C.; Qian, P.; Lu, X.; Sun, B.; Zhang, X.; Wang, L.; Gao, X.; Li, H.; Chen, Z.; et al. Gd-metallofullerenol nanomaterial as non-toxic breast cancer stem cell-specific inhibitor. Nat. Commun. 2015, 6, 5988. [CrossRef]

50. Kang, S.G.; Zhou, G.; Yang, P.; Liu, Y.; Sun, B.; Huynh, T.; Meng, H.; Zhao, L.; Xing, G.; Chen, C.; et al. Molecular mechanism of pancreatic tumor metastasis inhibition by $\mathrm{Gd}_{\mathrm{C}} \mathrm{C}_{82}(\mathrm{OH})_{22}$ and its implication for de novo design of nanomedicine. Proc. Natl. Acad. Sci. USA 2012, 109, 15431-15436. [CrossRef]

51. Zhu, H.; Chen, H.; Wang, J.; Zhou, L.; Liu, S. Collagen stiffness promoted non-muscle-invasive bladder cancer progression to muscle-invasive bladder cancer. Oncol. Targets Ther. 2019, 12, 3441-3457. [CrossRef] [PubMed]

52. Egeblad, M.; Rasch, M.G.; Weaver, V.M. Dynamic interplay between the collagen scaffold and tumor evolution. Curr. Opin. Cell. Biol. 2010, 22, 697-706. [CrossRef] [PubMed]

53. Yin, X.; Zhao, L.; Kang, S.-G.; Pan, J.; Song, Y.; Zhang, M.; Xing, G.; Wang, F.; Li, J.; Zhou, R.; et al. Impacts of fullerene derivatives to regulate the structure and assembly of collagen molecules. Nanoscale 2013, 5, 7341-7348. [CrossRef] [PubMed]

54. Eble, J.A.; Niland, S. The extracellular matrix in tumor progression and metastasis. Clin. Exp. Metastas 2019, 36, 171-198. [CrossRef] [PubMed]

55. He, X.; Lee, B.; Jiang, Y. Cell-ECM interactions in tumor invasion. Adv. Exp. Med. Biol. 2016, 936, 73-91. [PubMed]

56. Yamada, K.M. Cell biology: Tumour jailbreak. Nature 2003, 424, 889-890. [CrossRef] 
57. Merchant, N.; Nagaraju, G.P.; Rajitha, B.; Lammata, S.; Jella, K.K.; Buchwald, Z.S.; Lakka, S.S.; Ali, A.N. Matrix metalloproteinases: Their functional role in lung cancer. Carcinogenesis 2017, 38, 766-780. [CrossRef] [PubMed]

58. Conlon, G.A.; Murray, G.I. Recent advances in understanding the roles of matrix metalloproteinases in tumour invasion and metastasis. J. Pathol. 2019, 247, 629-640. [CrossRef]

59. Deryugina, E.I.; Quigley, J.P. Matrix metalloproteinases and tumor metastasis. Cancer Metast. Rev. 2006, 25, 9-34. [CrossRef]

60. Puerta, D.T.; Lewis, J.A.; Cohen, S.M. New beginnings for matrix metalloproteinase inhibitors: Identification of high-affinity zinc-binding groups. J. Am. Chem. Soc. 2004, 126, 8388-8389. [CrossRef]

61. Coussens, L.M.; Fingleton, B.; Matrisian, L.M. Matrix metalloproteinase inhibitors and cancer-trials and tribulations. Science 2002, 295, 2387-2392. [CrossRef] [PubMed]

62. Tlatli, R.; El Ayeb, M. MMP inhibitors and cancer treatment trials, limitations and hopes for the future. Arch. Inst. Pasteur. Tunis. 2013, 90, 3-21. [PubMed]

63. John, A.; Tuszynski, G. The role of matrix metalloproteinases in tumor angiogenesis and tumor metastasis. Pathol. Oncol. Res. 2001, 7, 14-23. [CrossRef] [PubMed]

64. Cornelius, L.A.; Nehring, L.C.; Harding, E.; Bolanowski, M.; Welgus, H.G.; Kobayashi, D.K.; Pierce, R.A.; Shapiro, S.D. Matrix metalloproteinases generate angiostatin: Effects on neovascularization. J. Immunol. 1998, 161, 6845-6852. [PubMed]

65. Behr, J.-P.; Anslyn E, V. The lock and key principle. The state of the art-100 years on. Angew. Chem. Eng. Edi. 1995, 34, 2293.

66. Congreve, M.; Langmead, C.J.; Mason, J.S.; Marshall, F.H. Progress in structure based drug design for G protein-coupled receptors. J. Med. Chem. 2011, 54, 4283-4311. [CrossRef] [PubMed]

67. Wang, T.; Wu, M.-B.; Lin, J.-P.; Yang, L.-R. Quantitative structure-activity relationship: Promising advances in drug discovery platforms. Expert Opin. Drug Discov. 2015, 10, 1283-1300. [CrossRef] [PubMed]

68. Tang, J.; Xing, G.; Yuan, H.; Cao, W.B.; Jing, L.; Gao, X.F.; Qu, L.; Cheng, Y.; Ye, C.; Zhao, Y.; et al. Tuning electronic properties of metallic atom in bondage to a nanospace. J. Phys. Chem. B 2005, 109, 8779-8785. [CrossRef] [PubMed]

69. Tang, J.; Xing, G.; Zhao, F.; Yuan, H.; Zhao, Y. Modulation of structural and electronic properties of fullerene and metallofullerenes by surface chemical modifications. J. Nanosci. Nanotechnol. 2007, 7, 1085-1101. [CrossRef]

70. Kang, S.; Huynh, T.; Zhou, R. Non-destructive inhibition of metallofullerenol Gd@C $82(\mathrm{OH})_{22}$ on WW domain: Implication on signal transduction pathway. Sci. Rep. 2012, 2, 957. [CrossRef]

71. Kang, S.; Huynh, T.; Zhou, R. Metallofullerenol Gd@ $\mathrm{C}_{82}(\mathrm{OH})_{22}$ distracts the proline-rich-motif from putative binding on the SH3 domain. Nanoscale 2013, 5, 2703-2712. [CrossRef] [PubMed]

72. Liu, X.; Ying, X.; Li, Y.; Yang, H.; Hao, W.; Yu, M. Identification differential behavior of Gd@C $\mathrm{C}_{82}(\mathrm{OH})_{22}$ upon interaction with serum albumin using spectroscopic analysis. Spectrochim. Acta A Mol. Biomol. Spectrosc. 2018, 203, 383-396. [CrossRef] [PubMed]

73. Chen, S.H.; Kang, S.-G.; Luo, J.; Zhou, R. Charging nanoparticles: Increased binding of Gd@C $\mathrm{C}_{82}(\mathrm{OH})_{22}$ derivatives to human MMP-9. Nanoscale 2018, 10, 5667-5677. [CrossRef] [PubMed]

74. Zuo, G.; Huang, Q.; Wei, G.; Zhou, R.; Fang, H. Plugging into proteins: Poisoning protein function by a hydrophobic nanoparticle. ACS Nano 2010, 4, 7508-7514. [CrossRef] [PubMed]

75. Kang, S.G.; Araya-Secchi, R.; Wang, D.Q.; Wang, B.; Huynh, T.; Zhou, R.H. Dual Inhibitory Pathways of Metallofullerenol Gd@ $\mathrm{C}_{82}(\mathrm{OH})_{22}$ on Matrix Metalloproteinase-2: Molecular insight into drug-like nanomedicine. Sci. Rep. 2014, 4, 4775. [CrossRef]

76. Ge, C.; Meng, L.; Xu, L.; Bai, R.; Du, J.; Zhang, L.; Li, Y.; Chang, Y.; Zhao, Y.; Chen, C. Acute pulmonary and moderate cardiovascular responses of spontaneously hypertensive rats after exposure to single-wall carbon nanotubes. Nanotoxicology 2012, 6, 526-542. [CrossRef]

77. Chen, H.; Wang, B.; Gao, D.; Guan, M.; Zheng, L.; Ouyang, H.; Chai, Z.; Zhao, Y.; Feng, W. Broad-spectrum antibacterial activity of carbon nanotubes to human gut bacteria. Small 2013, 9, 2735-2746. [CrossRef]

78. Jia, G.; Wang, H.; Yan, L.; Wang, X.; Pei, R.; Yan, T.; Zhao, Y.; Guo, X. Cytotoxicity of carbon nanomaterials: Single-wall nanotube, multi-wall nanotube, and fullerene. Environ. Sci. Technol. 2005, 39, 1378-1383. [CrossRef] 
79. Jiao, F.; Liu, Y.; Qu, Y.; Li, W.; Zhou, G.; Ge, C.C.; Li, Y.F.; Sun, B.Y.; Chen, C. Studies on anti-tumor and antimetastatic activities of fullerenol in a mouse breast cancer model. Carbon 2010, 48, 2231-2243. [CrossRef]

80. Gross, J.; Lapiere, C.M. Collagenolytic activity in amphibian tissues: A tissue culture assay. Proc. Natl. Acad. Sci. USA 1962, 48, 1014-1022. [CrossRef]

81. Egeblad, M.; Werb, Z. New functions for the matrix metalloproteinases in cancer progression. Nat. Rev. Cancer 2002, 2, 161-174. [CrossRef] [PubMed]

2019 by the authors. Licensee MDPI, Basel, Switzerland. This article is an open access article distributed under the terms and conditions of the Creative Commons Attribution (CC BY) license (http://creativecommons.org/licenses/by/4.0/). 